\title{
PENGARUH VALUE BASED PRICING TERHADAP KEPUTUSAN BERKUNJUNG DI TAMAN REKREASI KOTA BUNGA CIANJUR
} (Survei terhadap Wisatawan Nusantara Taman Rekreasi Kota Bunga Cianjur)

\author{
Apriani Silalahi \\ Rini Andari \\ Manajemen Pemasaran Pariwisata FPIPS UPI
}

\begin{abstract}
Kabupaten Cianjur is one of regencies in West java has tourism potential can be relied, and the one of destination is Taman Rekreasi Kota Bunga. Taman Rekreasi Kota Bunga is a recreation area that offers a variety of tourist attraction with the unique feel for the tourist. The number of tourist visits on Taman Rekreasi Kota Bunga has increase from 2008 to 2010. Value based pricing is one of marketing strategy that can be used to increase the number of visit. In connection with these to research studies conducted on the influence value based pricing toward visiting decision Taman Rekreasi Kota Bunga. The purpose of this research is to find value based pricing influence visiting decisions to Taman Rekreasi Kota Bunga. Value based pricing consists of discounting, penetration pricing, value pricing, market segmen pricing. Technique of sampling is systematic random sampling. The method in that used in this research is explanatory survey by using ordinal scale. Analyze from this research use Path Analysis with a computer software tools SPSS 19.0. The result of this research is value based pricing influence significantly $86,6 \%$ and the rest influence other factors. Based on the result of statistical test results were obtained, there were four variables of value based pricing which had an influence on visiting decisions of discounting, penetration pricing, market segmen pricing and there was one variables that had no effect on visiting decisions was value pricing. That it can be concluded that direct discounting, penetration pricing, market segmen pricing strong influence the visiting decision on Taman Rekreasi Kota Bunga.
\end{abstract}

Keywords: Value based pricing, Visiting Decision

\section{PENDAHULUAN}

\subsection{Latar Belakang}

Peranan pariwisata dapat meningkatkan kesejahteraan masyarakat tidak dapat diragukan lagi. Pariwisata merupakan suatu fenomena yang ditimbulkan oleh salah satu bentuk kegiatan manusia, yaitu kegiatan perjalanan untuk meninggalkan tempat tinggal hanya untuk mencari kesenangan semata bukan untuk mencari nafkah, Kabupaten Cianjur memiliki objek wisata yang menarik antara lain atraksi wisata Pendakian Gunung Gede Pangrango, Kebun Raya Cibodas, Taman Rekreasi Kota Bunga, Taman Bunga Nusantara, Istana Kepresidenan Cipanas, Makam Dalem Cikundul, Wisata Tirta Jangari, Wisata Tirta Calincing, Pantai Apra, dan Pantai Jayanti. Objek wisata yang berada di Kabupaten Cianjur dijadikan sumber potensi pariwisata Kabupaten Cianjur untuk menarik wisatawan datang berkunjung ke Kabupaten Cianjur.

Salah satu daya tarik wisata adalah Taman Rekreasi Kota Bunga. Berikut adalah data kunjungan Taman Rekreasi Kota Bunga Tahun 2008-2010:
TABEL 1

JUMLAH TARGET DAN DATA KUNJUNGAN WISATAWAN

NUSANTARA KE KOTA BUNGA TAHUN 2008-2010

\begin{tabular}{|c|c|c|c|}
\hline No & Tahun & $\begin{array}{c}\text { Target } \\
\text { Kunjungan } \\
\text { Wisatawan }\end{array}$ & $\begin{array}{c}\text { Data } \\
\text { Kunjungan } \\
\text { Wisatawan } \\
\text { Nusantara }\end{array}$ \\
\hline 1 & 2008 & 300.000 & 464.285 \\
\hline 2 & 2009 & 450.000 & 572.325 \\
\hline 3 & 2010 & 500.000 & 644.857 \\
\hline
\end{tabular}

Sumber: Taman Rekreasi Kota Bunga(2010)

Tabel 1 mengenai target pertumbuhan wisatawan nusantara ke daya tarik wisata Taman Rekreasi Kota Bunga di atas dapat dilihat bahwa target wisatawan nusantara pada tahun 2008 sampai 2009 mengalami peningkatan target wisatawan sebesar 450.000 begitupun pada tahun 2010 Taman Rekreasi Kota Bunga mengalami peningkatan sebesar 500.000 wisatawan nusantara. Dapat dilihat bahwa data kunjungan wisatawan nusantara sampai sekarang ini sudah melebihi target kunjungan dan mengalami peningkatan. Hal ini dapat disimpulkan dengan meningkatnya data kunjungan yang melebihi target kunjungan 
dapat dikatakan baik dan harus dipertahankan. Mempertahankan tingkat kunjungan merupakan pendapatan dan hal yang terpenting bagi Taman Rekreasi Kota Bunga.

\subsection{Rumusan Masalah}

Berdasarkan uraian tersebut, dapat dirumuskan beberapa masalah untuk memperoleh penelitian sebagai berikut:

1. Bagaimana value based pricing di Objek wisata Taman Rekreasi Kota Bunga

2. Bagaimana keputusan berkunjung di Objek wisata Taman Rekreasi Kota Bunga

3. Seberapa besar pengaruh value based pricingterhadap keputusan berkunjung di Objek wisata Taman Rekreasi Kota Bunga.

\subsection{Tujuan Penelitian}

Berdasarkan dari rumusan masalah yang telah dikemukakan di atas, maka tujuan dalam penelitian ini untuk memperoleh temuan mengenai:

Penelitian ini dimaksudkan untuk mengungkapkan data dan informasi yang berhubungan dengan penciptaan keputusan berkunjung melalui value based pricing kewisata Taman Rekreasi Kota Bunga Cianjur dengan tujuan untuk memperoleh temuan mengenai:

1. Value based pricing di Objek wisata Taman Rekreasi Kota Bunga

2. Pengaruh keputusan berkunjung diObjek Wisata Taman Rekreasi Kota Bunga

3. Memperoleh temuan mengenai seberapa besar pengaruh Value based pricing terhadap keputusan berkunjung di Objek wisata Taman Rekreasi Kota Bunga.

\subsection{Kegunaan Penelitian}

Kegunaan dari penelitian diharapkan bisa berguna bagi semua pihak yang berkepentingan terutama terkait dengan penelitian.

\section{Secara Teoritis}

Hasil penelitian ini diharapkan peneliti dapat memberikan konstribusi pada ilmu mengenai Manajemen Pemasaran Pariwisata dan khususnya mengenai pentingnya akan value based pricing pariwisata terhadap keputusan berkunjung.

\section{Secara Praktis}

Hasil penelitian ini diharapkandapat memberikan masukan bagi semua pihak khususnya bagi pengelola daya tarik wisata
Taman Rekreasi Kota Bunga dan daya tarik wisata akan pentingnya value based pricing pariwisata yang dapat meningkatkan wisatawan.

\section{KAJIAN PUSTAKA}

\subsection{Kerangka Pemikiran}

Marketing atau pemasaran merupakan kegiatan penting dari perusahaan yang menghasilkan produk untuk dijual, dengan tujuan memperoleh keuntungan. Menurut Philip Kotler and Kevin Lane Keller (2009:5) mendefinisikan pemasaran dalam dua sisi, yaitu sisi pemasaran sosial dan pemasaran manajerial. Definisi sosial menunjukkan peran yang dimainkan oleh pemasaran di dalam masyarakat. Pamasaran adalah "proses sosial yang di dalamnya individu dan kelompok mendapatkan apa yang mereka perlukan dan inginkan dengan menciptakan, menawarkan, dan saling bertukar produk dan layanan yang bernilai dengan bebas dengan pihak lain." Sedangkan dalam definisi manajerial, pemasaran sering disebut sebagai "seni untuk menjual produksi."

Pendapat lain dari Venkatesh dan Penaloza dalam Fandy Tjiptono, Gregorius Chandra dan Dedi Adriana (2008:4) mengungkapkan bahwa pemasaran adalah serangkaian aktivitas yang dilakukan perusahaan untuk menstimulasi permintaan atas produk atau jasanya dan memastikan bahwa produk dijual dan disampaikan kepada para pelanggan.

Berdasarkan definisi-definisi tersebut dapat dikatakan secara singkat bahwa pemasaran itu merupakan seni di mana satu sisi pemasaran berfungsi untuk memenuhi kebutuhan dan keinginan konsumen dan di sisi lain berfungsi untuk memperoleh keuntungan bagi perusahaan. Agar mampu sehingga dapat menghasilkan produk yang sesuai dengan keinginan dan kebutuhan konsumen serta memenangkan persaingan dapat diciptakan perusahaan dengan melakukan kegiatan marketing mix.

Menurut Buchari Alma (2007:205): "Marketing mix adalah strategi mencampur kegiatan-kegiatan marketing, agar dicari kombinasi maksimal sehingga mendatangkan hasil paling memuaskan. Marketing mix merupakan seperangkat alat pemasaran yang digunakan perusahaan untuk terus-menerus mencapai tujuan pemasarannya di pasar sasaran”. (Philip Kotler, 2009:101)

Menurut Fandy Tjiptono (2006:200) marketing mix merupakan suatu strategi penetapan harga dimana penyedia jasa 
melakukan kesepakatan atas harga dengan ketidakpastian suatu pelanggan besarnya biaya actual yang harus mereka bayar. Para pemasar menggunakan sejumlah alat untuk mendapatkan yanggapan yang diinginkan pasar sasaran mereka. Alat-alat itu membentuk suatu suatu bauran pemasaran yang dikenal dengan marketing mix. Marketing mix merupakan kombinasi variabel atau kegiatan yang merupakan inti dari system pemasaran untuk mempengaruhi tanggapan konsumen dalam pasar sasarannya. Variabel atau kegiatan tersebut perlu dikombinasikan dan dikoordinasikan oleh perusahaan seefektif mungkin, dalam melakukan kegiatan pemasarannya.

Penetapan harga biasanya dilakukan dengan menambah persentase di atas nilai atau besarnya biaya produksi. Pendekatan ini, bagaimanapun juga dapat mengakibatkan kehilangan manfaat dalam strategi pemasaran. Perusahaan-perusahaan yang bergerak di bidang jasa perlu menggunakan strategi penentuan harga agar mampu bersaing dalam pasar yang kompetitif.

Armstrong dan Kotler mengemukakan bahwa strategi penetapan harga terdiri dari strategi memiliki dimensi Penetapan harga lini produk. Penetapan harga keistimewaan produk, penetapan harga produk sampingan, penetapan harga bundle produk.

Strategi penetapan harga sejumlah uang yang ditagihkan untuk suatu produk atau jasa, jumlah nilai yang di pertukarkan konsumen untuk manfaat memiliki atau menggunakan produk atau jasa.

Menurut Kotler dan Armstrong (2008:251) menyatakan bahwa "Harga adalah atribut produk yang paling unik untuk mempertimbangkan sebelum melakukan tindakan pembelian”. Sedangkan menurut Fandy Tjiptono (2007:467), setiap perusahaan tidak hanya menetapkan satu harga tetapi lebih berupa struktur penetapan harga (Pricing Structure) yang mencakup item-item yang berbeda di setiap lini produk.

Pengertian di atas didukung dengan adanya teori pendukung pricing strategy, salah satu elemen yang ada dalam marketing mix yaitu price. Price adalah keputusan distribusi menyangkut kemudahan akses terhadap jasa bagi para pelanggan potensial. Price berdasarkan value based pricing menyangkut:

a. Nilai adalah harga murah yang terdiri dari:

1. Discounting yaitu menawarkan diskon atau potongan harga untuk mengkomunikasikan kepada para pembeli yang sensitif terhadap harga bahwa mereka mendatkan nilai yang diharapkan.

2. Penetration pricing yaitu menetapkan harga murah untuk suatu jasa baru dengan tujuan mendorong pencobaan produk dan pemakaian lebih luas. Strategi ini efektif dalam tahap perkenalan dalam situasi volume jasa sangat sensitif terhadap harga, sekalipun dalam tahap perkenalan pada siklus hidup produk, ada kemungkinan untuk mencapai skala ekonomis dalam biaya perunit melalui oversai pada volume besar, jasa perusahaan menghadapi ancaman kompetisi potensial yang intensif segera setelah introduksi jasa baru, tidak ada kelompok pembeli yang bersedia membayar harga lebih mahal untuk mendapatkan jasa bersangkutan.

b. Nilai adalah kualitas yang saya dapatkan dari harga yang saya bayarkan, yang terdiri dari:

1. Value pricing yaitu penetapan harga jasa yang didasarkan pada konsep "giving more for less". Dimana sejumlah jasa dikemas dalam satu paket yang memiliki daya tarik bagi berbagai kelompok.

2. Market segmentation pricing yaitu menetapkan harga berbeda bagi berbagai segmen pelanggan yang berbeda atas dasar perbedaan persepsi terhadap tingkat kualitas jasa. Sekalipun, mungkin biaya penyediaan jasa bagi masing-masing segmen tersebut tidak berbeda.

Saat seseorang membeli suatu produk baik barang maupun jasa, belum tentu orang tersebut telah memutuskan berkunjung untuk membeli sebuah produk tersebut merupakan produk yang paling disukainya.

Pricing strategy sangat mempengaruhi keputusan pembelian produk atau jasa yang mereka butuhkan. Menurut Sheryl E.Kimes dalam jurnal Pricing andRevenue Management 2009 yang mengungkapkan "In order to successfully use price as a strategyc weapon, firms must address two questions: what price to charge and how to determine which customers or market segments should be offered those price determine his decision". Sedangkan Stowe Shoemaker and Anna S.Mattila dalam jurnal Pricing In Service 2009 yang berpendapat "service have characteristics that make pricing in a different service with the goods".

Proses keputusan untuk berkunjung dipegaruhi oleh bermacam-macam dorongan. Walaupun keputusan untuk berkunjung dan membeli sama sekali tidak bisa dipaksakan 
oleh pedagang atau penguasaha, akan tetapi karena adanya motif-motif pembelian itu maka para pengusaha atau pedagang dapat mempengaruhi atau memperbesar kecenderungan para pengunjung tersebut untuk berkunjung dengan berbagai cara diantaranya dengan mengadakan pricing strategy berdasarkan value based pricing yang baik dan menarik agar calon pengunjung tertarik.

Kotler dan Keller (2009:202) mengemukakan bahwa: Keputusan pembelian ada pada tahap keempat dalam proses keputusan pembelian dimana keputusan pembelian terdiri dari lima tahapan yaitu:1) Pemilihan produk, 2) Pemilihan merek, 3) Pemilihan penyalur, 4) Waktu pembelian, 5) Jumlah pembelian.

Keputusan pembelian dapat juga mengukur keputusan berkunjung, akan tetapi memakai empat tahapan yaitu : 1) Pemilihan produk, 2) Pemilihan Distribusi, 3) Pemilihan Waktu berkunjung, 4) Jumlah kunjungan.

Untuk mendorong keputusan berkunjung dari pengunjung terhadap produknya, sebuah objek wisata belanja dituntut untuk memperlihatkan produk yang unggul yaitu salah satunya melalui pemilihan desain produk yang menarik, dan dipromosikan dan diantaranya melalui value based pricing yang baik, agar mampu memenuhi selera pengunjung secara memuaskan.

Setiap tahap yang dilalui pengunjung tersebut, sebuah harga harus dapat menggerakan pengunjung dari tahap awal sampai tahap akhir melalui alat strateginya yaitu value based pricing, dengan alat daya tarik suasana yang nyaman dan menarik. Variabel ini mempunyai peranan penting dalam mempengaruhi keputusan berkunjung.

Sangat jelas bahwa dalam proses perilaku keputusan berkunjung, value based pricing memegang peranan penting yang harus diperhatikan oleh pengusaha dalam mempengaruhi keputusan berkunjung

Konsep keputusan pembelian dapat mengukur keputusan berkunjung, Buchari
Alma (2007:57) mengemukakan bahwa "keputusan kunjungan wisatawan yang asalnya dipengaruhi oleh lingkungan, kebudayaan, keluarga dan sebagainya, akan membentuk suatu sikap pada diri individu, kemudian melakukan berkunjung untuk pembelian".

Proses keputusan untuk berkunjung dipegaruhi oleh bermacam-macam dorongan. Walaupun keputusan untuk berkunjung dan membeli sama sekali tidak bisa dipaksakan oleh pedagang atau penguasaha, akan tetapi karena adanya motif-motif pembelian itu maka para pengusaha atau pedagang dapat mempengaruhi atau memperbesar kecenderungan para pengunjung tersebut untuk berkunjung dan membeli dengan berbagai cara diantaranya dengan mengadakan valuebased pricing yang baik dan menarik agar calon pengunjung tertarik.

Kotler dan Keller (2009:202) mengemukakan bahwa: Keputusan pembelian ada pada tahap keempat dalam proses keputusan pembelian dimana keputusan pembelian terdiri dari lima tahapan yaitu:1) Pemilihan produk, 2) Pemilihan merek, 3) Pemilihan penyalur, 4) Waktu pembelian, 5) Jumlah pembelian.

Keputusan pembelian dapat juga mengukur keputusan berkunjung, akan tetapi memakai empat tahapan yaitu : 1) Pemilihan produk, 2) Pemilihan Distribusi, 3) Pemilihan Waktu berkunjung, 4) Jumlah kunjungan.

Untuk mendorong keputusan berkunjung dari pengunjung terhadap produknya, sebuah objek wisata dituntut untuk memperlihatkan produk dan jasa yang unggul yaitu salah satunya melalui onjek wisata yang menarik, dan dipromosikan dan diantaranya melalui valuebased pricing yang baik, agar mampu memenuhi selera pengunjung secara memuaskan

Berdasarkan uraian yang telah dikemukakan, maka peneliti akan menjabarkan kedalam kerangka pemikiran. Kerangka pemikiran tersebut disajikan pada gambar berikut ini: 


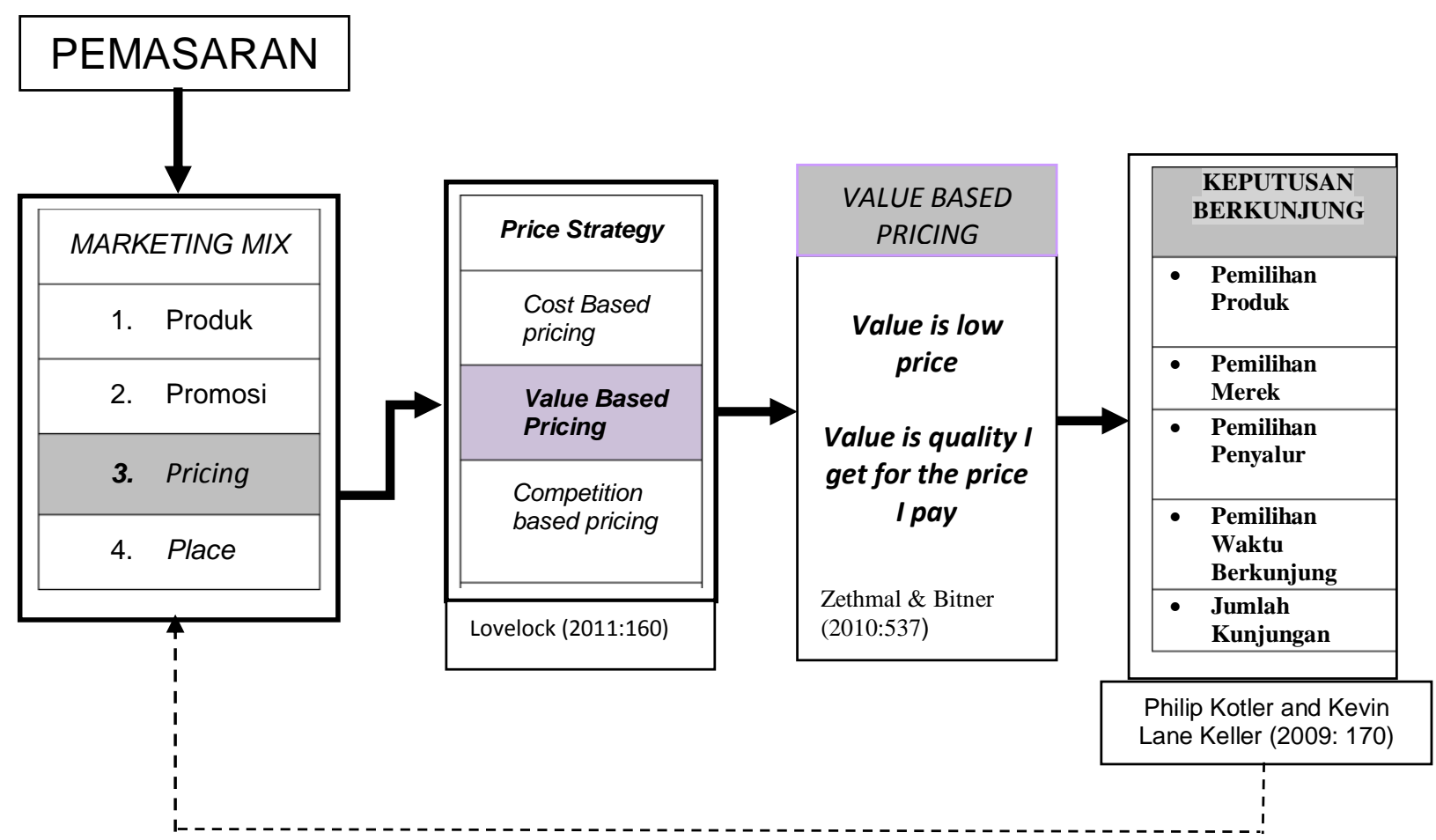

Variabel yang diteliti

Umpan Balik

GAMBAR 1

KERANGKA PEMIKIRAN PENGARUH VALUE BASED PRICING TERHADAP KEPUTUSAN BERKUNJUNG DI TAMAN REKREASI KOTA BUNGA CIANJUR

\subsection{Hipotesis Penelitian}

Ulber Silalahi

(2009:160) mengutarakan bahwa hipotesis merupakan pernyataan atau jawaban tentatif atas masalah dan kemudian hipotesis dapat diversifikasi hanya setelah hipotesis diuji secara empiris. Jadi, hipotesis juga dapat dinyatakan sebagai jawaban teoritis terhadap rumusan masalah penelitian, belum merupkan jawaban emprik.

Berdasarkan penyusunan hipotesis penelitian ini, didukung oleh beberapa premis yang mendukung bahwa pricing strategy mempunyai pengaruh terhadap keputusan berkunjung sebagai berikut:

1. Harga adalah salah satu faktor penting bagi konsumen dalam mengambil keputusan untuk melakukan transaksi atau tidak (Engel, Blackwell \& Minard dan Kotler, 2008 dalam Papadri,(2008).

2. Konsumen memiliki informasi yang sempurna tentang harga dan selalu berupaya membandingan dengan produk alternatif maka peranan price awareness dan prices conciouness sangat tinggi dalam proses pengambilan keputusan (Monroe, 2007 dalam Papadri,(2008)

3. Kotler (2008:18) yang menyebutlkan "Hargamerupakan penentu utama pilihan pembeli".

Berdasarkan uraian permasalahanpermasalahan di atas, maka penulis merumuskan bahwa:

"Terdapat pengaruh antara value based pricing terhadap keputusan berkunjung di Taman Rekreasi Kota Bunga"

\section{III.METODE PENELITIAN}

\subsection{Objek Penelitian}

Penelitian ini dilakukan terhadap para pengunjung kawasan objek wisata Taman Rekreasi Kota Bunga Cipanas Cianjur. Variabel bebas adalah value based pricing yangterdiri dari value is low price $(X 1)$ :discounting, penetration pricing andvalue is the quality I get for the price I pay (X2):value pricing,market segmentation pricing, sedangkan variabel terikat adalah keputusan berkunjung yang terdiri dari pemilihan produk/jasa, pemilihan penyalur, 
pemilihan waktu berkunjung, jumlah kunjungan.

Adapun objek yang dijadikan responden adalah pengunjung dari wisata Taman Rekreasi Kota Bunga Cipanas Cianjur

\subsection{Metode Penelitian}

Berdasarkan variabel-variabel yang diteliti maka jenis penelitian ini adalah penelitian deskriftif dan verifikatif. (Sugiyono 2011:147)

Penelitian deskriptif adalah penelitian yang dilakukan untuk mengetahui keberadaan variabel mandiri, baik satu variabel atau lebih variabel (variabel yang berdiri sendiri) tanpa membuat perbandingan dan atau mencari hubungan variabel satu sama lain.

Melalui jenis penelitian deskriptif maka dapat diperoleh deskripsi mengenai penerapan value based pricing pada kawasan objek wisata Taman Rekreasi Kota Bunga Cipanas Cianjur serta pandangan responden tentang keputusan berkunjung di kawasan wisata Taman Rekreasi Kota Bunga Cipanas Cianjur. Menurut Sugiyono (2008:36), Penelitian verifikatif adalah penelitian yang membandingkan keberadaan satu variabel atau lebih pada dua atau lebih sampel yang berbeda, atau pada waktu yang berbeda. Sedangkan jenis penelitian verifikatif menguji kebenaran suatu hipotesis yang dilakukan melalui pengumpulan data di lapangan, dalam hal ini penelitian verifikatif bertujuan untuk mengetahui pengaruhvalue based pricingterhadap keputusan berkunjung.

Berdasarkan jenis penelitiaannya yaitu penelitian deskriptif dan verifikatif maka metode yang digunakan dalam penelitian ini adalah survey explanatory. Menurut Kenlinger yang dikutip dari buku Sugiyono (2011:147) adalah :
Metode survey yaitu metode penelitian yang dilakukan pada populasi besar maupun kecil, tetapi data yang dipelajari adalah datadata dari sampel yang diambil dari populasi tersebut, sehingga ditemukan kejadiankejadian relatif, distribusi, dan hubunganhubungan antar variabel sosiologis maupun psikologis

\subsection{Operasionalisasi Variabel}

Operasionalisasi variabel adalah merupakan kegiatan mengurai variabel menjadi sejumlah variabel operasional atau variabel empiris (indikator, item) yang merujuk langsung pada hal-hal yang dapat diamati atau diukur.

Variabel yang diteliti adalah pengaruh value based pricing $(\mathrm{X})$ yang tediri darivalue is low price:discounting, penetration pricing andvalue is quality I get for the price I pay:value pricing,market segmentation pricing terhadap keputusan berkunjung yang terdiri dari pemilihan merek, pemilihan produk/jasa, pemilihan penyalur, pemilihan waktu berkunjung, jumlah kunjungan.Penelitian ini menggunakan skala hybrid ordinal interval. Skala hybrid ordinal interval merupakan suatu skala yang secara artifisial ditransformasi ke dalam interval oleh peneliti, dalam hal ini skala ordinal ditransformasi ke dalam apa yang di asumsikan sebagai skala interval. Jadi hybrid ordinal interval pada dasarnya adalah skala ordinal tetapi di asumsikan memiliki karakteristik jarak yang diasumsikan (assumed distance property) sehingga peneliti melakukan beberapa jenis analisis statistik yang tingkatannya lebih tinggi (Asep Hermawan 2006:124-125). Secara lebih rinci operasionalisasi masing-masing variabel itu dapat terlihat dalam Tabel 3.1 berikut : 
TABEL 2

OPERASIONALISASI VARIABEL

\begin{tabular}{|c|c|c|c|c|c|}
\hline $\begin{array}{c}\text { Variabel/Sub } \\
\text { variable }\end{array}$ & $\begin{array}{l}\text { Konsep } \\
\text { Variabel }\end{array}$ & Indikator & Ukuran & Skala & $\begin{array}{c}\text { No } \\
\text { Item }\end{array}$ \\
\hline 1 & 2 & 3 & 4 & 5 & 6 \\
\hline \multirow[t]{4}{*}{$\begin{array}{l}\text { Value Based } \\
\text { Pricing }\end{array}$} & $\begin{array}{l}\text { Penetapan harga harga } \\
\text { dilihat dari produk yang } \\
\text { dirasakan oleh pelanggan } \\
\text { baik manfaat ekonomis, } \\
\text { fungsional, maupun } \\
\text { psikologis (Lovelock } \\
\text { 2011:160) }\end{array}$ & & & & \\
\hline & \multirow{3}{*}{$\begin{array}{l}\text { Apabila harga moneter } \\
\text { merupakan determinan nilai } \\
\text { yang paling penting bagi } \\
\text { pelanggan, maka perusahaan } \\
\text { hanya berfokus pada harga } \\
\text { (Zeithmal and Bitner, 2009) }\end{array}$} & \multirow[t]{3}{*}{ Value is low price } & $\begin{array}{ll}\text { 1. } & \text { Tingkat } \\
\text { kemenarikan } \\
\text { diskon yang } \\
\text { ditawarkan }\end{array}$ & Ordinal & B.I.1 \\
\hline & & & $\begin{array}{ll}\text { 2. } & \text { Tingkat } \\
& \text { kesesuaian } \\
& \text { diskon yang } \\
& \text { ditawarkan }\end{array}$ & Ordinal & B.I.2 \\
\hline & & & $\begin{array}{ll}\text { 3. } & \text { Tingkat } \\
& \text { Kesesuaian } \\
& \text { harga murah } \\
& \text { sesuai kualitas } \\
& \text { yang didapat } \\
\end{array}$ & Ordinal & B.I.3 \\
\hline & \multirow{3}{*}{$\begin{array}{l}\text { Pelanggan sangat } \\
\text { mempertimbang } \\
\text { kan kualitas dan harga } \\
\text { moneter. Tugas pemasar } \\
\text { adalah memahami kualitas } \\
\text { bagi pelanggan dan } \\
\text { kemudian memenuhi tingkat } \\
\text { kualitas yang sesuai. } \\
\text { (Zeithmal and Bitner, 2009) }\end{array}$} & \multirow[t]{3}{*}{$\begin{array}{c}\text { Value is quality I } \\
\text { get for the price I } \\
\text { pay }\end{array}$} & $\begin{array}{ll}\text { 1. } & \text { Tingkat } \\
\text { kesesuaian } \\
\text { kualitas dengan } \\
\text { harga yang } \\
\text { ditawarkan. } \\
\end{array}$ & Ordinal & B.II.4 \\
\hline & & & $\begin{array}{l}\text { 2. Tingkat Kessuaian } \\
\text { harga sesuai } \\
\text { segmen yang } \\
\text { ditawarkan }\end{array}$ & Ordinal & B.II.5 \\
\hline & & & $\begin{array}{l}3 \text { Tingkat } \\
\text { kemenarikan } \\
\text { harga untuk } \\
\text { segmen }\end{array}$ & Ordinal & B.II.6 \\
\hline $\begin{array}{c}\text { Keputusan } \\
\text { Berkunjung (Y) }\end{array}$ & $\begin{array}{l}\text { Pengunjung dapat } \\
\text { mengambil keputusan untuk } \\
\text { membeli sebuah produk } \\
\text { wisata atau menggunakan } \\
\text { uangnya untuk tujuan lain. }\end{array}$ & & & & \\
\hline
\end{tabular}

LANJUTAN TABEL 2

OPERASIONALISASI VARIABEL

\begin{tabular}{|c|c|c|c|c|c|}
\hline $\begin{array}{c}\text { Variabel/Sub } \\
\text { variable }\end{array}$ & $\begin{array}{l}\text { Konsep } \\
\text { Variabel }\end{array}$ & Indikator & Ukuran & Skala & $\begin{array}{l}\text { No } \\
\text { Item }\end{array}$ \\
\hline 1 & 2 & 3 & 4 & 5 & 6 \\
\hline $\begin{array}{c}\text { Keputusan } \\
\text { Berkunjung (Y) }\end{array}$ & $\begin{array}{l}\text { Pengunjung dapat } \\
\text { mengambil keputusan untuk } \\
\text { membeli sebuah produk } \\
\text { wisata atau menggunakan } \\
\text { uangnya untuk tujuan lain. }\end{array}$ & & & & \\
\hline & & \multirow[t]{2}{*}{$\begin{array}{l}\text { Pemilihan } \\
\text { Produk/Jasa wisata }\end{array}$} & $\begin{array}{l}\text { 1. } \\
\text { Tingkat } \\
\text { keunggulan } \\
\text { daya tarik } \\
\text { produk wisata } \\
\text { yang } \\
\text { ditawarkan } \\
\text { Kota Bunga. }\end{array}$ & Ordinal & C.I.1 \\
\hline & & & $\begin{array}{ll}\text { 2. } & \text { Tingkat } \\
\text { keunikan } \\
\text { produk/jasa } \\
\text { yang } \\
\text { ditawarkan } \\
\text { Kota Bunga. } \\
\end{array}$ & Ordinal & C.I.2 \\
\hline
\end{tabular}




\begin{tabular}{|c|c|c|c|c|c|}
\hline $\begin{array}{c}\text { Variabel/Sub } \\
\text { variable }\end{array}$ & $\begin{array}{c}\text { Konsep } \\
\text { Variabel } \\
\end{array}$ & Indikator & Ukuran & Skala & $\begin{array}{c}\text { No } \\
\text { Item }\end{array}$ \\
\hline \multirow[t]{10}{*}{1} & 2 & 3 & 4 & 5 & 6 \\
\hline & & & $\begin{array}{ll}\text { 3. } & \text { Tingkat } \\
\text { keberagaman } \\
\text { daya tarik Kota } \\
\text { Bunga. }\end{array}$ & Ordinal & C.I.3 \\
\hline & & \multirow[t]{2}{*}{ Merek objek wisata } & $\begin{array}{ll}1 . & \text { Tingkat } \\
& \text { kepopuleran } \\
& \text { Kota Bunga. }\end{array}$ & Ordinal & $\begin{array}{l}\text { C.II.4 } \\
\end{array}$ \\
\hline & & & $\begin{array}{ll}\text { 2. } & \text { Tingkat } \\
& \text { kepopuleran } \\
& \text { berdasarkan } \\
& \text { keputusan } \\
& \text { berkunjung } \\
& \text { Kota Bunga. }\end{array}$ & Ordinal & C.II.5 \\
\hline & & $\begin{array}{l}\text { Pemilihan Penyalur } \\
\text { wisatawan }\end{array}$ & $\begin{array}{ll}1 . & \text { Tingkat } \\
\text { kemudahan } \\
\text { mengakses } \\
\text { tempat tujuan. }\end{array}$ & Ordinal & $\begin{array}{l}\text { C.III. } \\
6\end{array}$ \\
\hline & & & $\begin{array}{ll}\text { 2. } & \text { Tingkat } \\
& \text { kesetrategisan } \\
& \text { kunjungan } \\
& \text { berdasarkan } \\
\text { tempat tujuan. } & \end{array}$ & Ordinal & $\begin{array}{l}\text { C.III. } \\
7\end{array}$ \\
\hline & & \multirow[t]{3}{*}{$\begin{array}{l}\text { Pemilihan Waktu } \\
\text { Berkunjung } \\
\text { perjalanan wisata }\end{array}$} & $\begin{array}{ll}1 . & \text { Tingkat } \\
& \text { keseringan } \\
& \text { melakukan } \\
& \text { kunjungan pada } \\
& \text { saat weekday }\end{array}$ & Ordinal & $\begin{array}{l}\text { C.IV. } \\
8\end{array}$ \\
\hline & & & $\begin{array}{ll}\text { 2. } & \text { Tingkat } \\
& \text { keseringan } \\
& \text { melakukan } \\
& \text { kunjungan pada } \\
& \text { saat weekend. }\end{array}$ & Ordinal & $\begin{array}{l}\text { C.IV. } \\
9\end{array}$ \\
\hline & & & $\begin{array}{ll}3 . & \text { Tingkat } \\
& \text { keseringan } \\
& \text { melakukan } \\
& \text { kunjungan pada } \\
& \text { saat hari libur. }\end{array}$ & Ordinal & $\begin{array}{l}\text { C.IV. } \\
10\end{array}$ \\
\hline & & $\begin{array}{l}\text { Jumlah Kunjungan } \\
\text { wisatawan }\end{array}$ & $\begin{array}{ll}\text { 1. } & \text { Tingkat } \\
\text { keseringan } \\
\text { berkunjung ke } \\
\text { tempat tujuan } \\
\text { dikunjungi pada } \\
\text { suatu saat. }\end{array}$ & Ordinal & $\begin{array}{l}\text { C.V.1 } \\
1\end{array}$ \\
\hline
\end{tabular}

\subsection{Metode Penarikan Sampel}

Sampel dalam penelitian ini yaitu pengunjung Kawasan Objek Wisata Taman Rekreasi Kota Bunga. Jumlah sampel yang diambil dalam penelitian ini sebesar 100 sampel dari jumlah populasi wisatawan nusantara pada tahun 2010 sebanyak 644.857 dengan menggunakan rumus Slovin.

\subsection{Prosedur Pengumpulan Data}

Pengumpulan data yang dilakukan penulis menggunakan teknik sebagai berikut.:

1. Wawancara

2. Observasi

3. Studi literatur

4. Angket/kuesioner

\subsection{Pengujian Hipotesis}

Teknik analisis yang digunakan dalam penelitian ini adalah analisis regresi linier berganda. Prosedur kerja perhitungan regresi linier berganda dalam penelitian ini adalah sebagai berikut:

\section{a. Pengujian Asumsi}

Menurut Wahid Sulaiman (2004:88), untuk memperoleh model regresi yang terbaik, dalam arti secara statistik adalah BLUE (Best Linear Unbiased Estimator), maka model regresi yang diajukan harus memenuhi persyratan uji asumsi normalitas, uji asumsi heteroskedasitas, uji asumsi multikolinearitas. 
1. Uji Asumsi Normalitas

Syarat pertama untuk melakukan analisis regresi adalah normalitas, sebagaimanan yang diungkapkan oleh Triton (2005:76) bahwa data sampel hendaknya memenuhi prasyarat distribusi normal. Data yang mengandung data ekstrim biasanya tidak memenuhi asumsi normalitas. Jika sebaran data mengikuti sebaran normal, maka populasi dari mana data diambil berdistribusi normal dan akan dianalisis menggunakan analisis parametrik.

Menurut Wahid Sulaiman (2004:88), untuk mendeteksi normalitas, digunakan Normal Probability Plot. Melalui plot ini, masing-masing nilai pengamatan dipasangkan dengan nilai harapan dari distribusi normal apabila sebaran data terletak di sekitar garis lurus yang melalui titik nol dan tidak mempunyai pola.

2. Uji Asumsi Heteroskedastisitas

Heteroskedastisitas adalah varian residual yang tidak konstan pada regresi sehingga akurasi hasil prediksi menjadi meragukan. Residu pada heteroskedastisitas semakin besar apabila pengamatan semakin besar. Menurut wahid Sulaiman (2004:106), suatu regresi dikatakan tidak terdeteksi heteroskedastis apabila penyebaran nilainilai residual terhadap harga-harga prediksi tidak membentuk suatu pola tertentu (meningkat atau menurun).

3. Uji Asumsi Multikolinearitas

Multikolinearitas adalah situasi adanya korelasi yang kuat antara variabel bebas yang satu dengan variabel bebas yang lainnya dalam analisis regresi. Apabila dalam analisis terdeteksi multikolinearitas maka angka estimasi koefisien regresi yang didapat akan mempunyai nilai yang tidak sesuai dengan substansi, sehingga dapat menyesatkan interpretasi. Menghitung koefisien korelasi sederhana antara sesama variabel bebas, jika terdapat koefisien korelasi sederhana yang mencapai atau melebihi 0,8 maka hal tersebut menunjukan terjadinya multikoleritas dalam regresi.

\section{b. Analisis regresi linier berganda}

Variabel yang dianalisis adalah variabel independent yaitu value is low price (X1), value is quality $i$ get for the price $i$ pay, $(\mathrm{X} 2)$, sedangkan variabel dependent adalah keputusan berkunjung (Y). Langkahlangkah dalam perhitungan menggunakan teknik analisis regresi linier berganda adalah sebagai berikut:

1. Menentukan model persamaan regresi linier berganda
Berikut adalah model persamaan regresi linier berganda $X_{1}, X_{2}$, dan $Y$ Dengan memperhatikan karakteristik variabel yang akan diuji, maka uji statistik yang digunakan adalah memalui perhitungan persamaan regresi untuk tiga prediktor yaitu:

$Y=a+b_{1} X_{1}+b_{2} X_{2}+b_{3} X_{3}+=+b_{3} X_{3}$

Keterangan:

$\mathrm{Y}=$ Keputusan Berkunjung

$\mathrm{a}=$ Intercep atau konstanta

$\mathrm{b}=$ Koefisien regresi

$\mathrm{X}_{1}=$ value is low price

$\mathrm{X}_{2}=$ value is quality $i$ get for the price $i$ pay

2. Menurut Sugiyono (2008:250) untuk mengetahui kuat rendahnya hubungan pengaruh, dapat diklasifikasikan sebagai berikut:

TABEL 3

PEDOMAN UNTUK MEMBERIKAN INTERPRETASI KOEFISIEN KORELASI

\begin{tabular}{|l|l|}
\hline Interval Koefisien & Klasifikasi \\
\hline $0,000-0,199$ & Sangat Rendah \\
\hline $0,200-0,399$ & Rendah \\
\hline $0,400-0,599$ & Sedang \\
\hline $0,600-0,799$ & Kuat \\
\hline $0,800-1,000$ & Sangat Kuat \\
\hline
\end{tabular}

Sumber: Sugiyono (2008:250)

3. Menguji signifikasi koefisien korelasi ganda secara simultan dengan membandingkan $F_{\text {hitung }}$ dengan $F_{\text {tabel }}$ dengan rumus:

$$
F_{\text {hitung }}=\frac{R^{2}(n-m-1)}{m\left(1-R^{2}\right)}
$$

(Riduwan \& Akdon, 2006:128)

Keterangan:

$\mathrm{F}_{\text {hitung }}=$ Nilai $\mathrm{F}$ yang dihitung

$\mathrm{R} \quad=$ Nilai koefisien korelasi ganda

$\mathrm{m}=$ Jumlah variabel bebas

$\mathrm{n} \quad=$ Jumlah sampel

Kriteria pengujian:

Jika $F_{\text {hitung }} \geq F_{\text {tabel }}$ artinya signifikan

Jika $F_{\text {hitung }} \leq \mathrm{F}_{\text {tabel }}$ artinya tidak signifikan

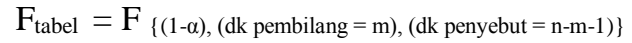

4. Menguji signifikasi koefisien korelasi ganda secara parsial dengan membandingkan $t_{\text {hitung }}$ dengan $t_{\text {tabel }}$ dengan menghitung nilai beta (koefisien jalur), yakni koefisien regresi yang distandarkan untuk mengetahui besarnya kontribusi masing-masing variabel independen terhadap variabel dependen dengan rumus:

$\rho_{\mathrm{YKX}}=\frac{S k}{S s^{5}}\left(b_{\mathrm{k}}\right) \quad$ (Kusnendi,2005:9) 
Keterangan:

$\rho_{\mathrm{YKX}}=$ Koefisien regresi yang distandarkan

$\mathrm{S}_{\mathrm{k}}=$ Standar deviasi variabel independen

$\mathrm{S}_{\mathrm{y}} \quad=\quad$ Standar deviasi variabel depeneden

$b_{k}=$ Koefisien regresi variabel indepeneden Xk yang terdapat dalam persamaan regresi

Secara statistik, hipotesis yang akan di uji dalam rangka pengambilan keputusan penerimaan atau penolakan dapat ditulis sebagi berikut:

Secara Simultan:

Ho: $\mathrm{PYX}=0$ : tidak berpengaruh valu based pricing terhadap keputusan berkunjung

$\mathrm{H} 1: \mathrm{PYX} \neq 0$ : terdapat pengaruh value based pricing terhadap

Secara Parsial: keputusan berkunjung.

PY $\mathrm{X}_{1.1}=0$, tidak terdapat pengaruh antara value is low price terhadap keputusan berkunjung di Taman Rekreasi Kota Bunga

$\mathrm{H} 1: \mathrm{PYX}_{1.1} \neq 0, \quad$ terdapat pengaruh value is low price terhadap keputusan berkunjung di Taman Rekreasi Kota Bunga

$\mathrm{H} \quad \mathrm{PYX}_{1.2}=0$, tidak terdapat pengaruh value is quality $i$ get for the price $i$ pay terhadap keputusan berkunjung di Taman Rekreasi Kota Bunga

H1: $\quad \mathrm{PYX}_{1.2} \neq 0$, terdapat pengaruh value is quality $i$ get for the price $i$ pay terhadap keputusan berkunjung di Taman Rekreasi Kota Bunga

\section{IV.HASIL PENELITIAN DAN PEMBAHASAN \\ 4.1. Tanggapan Responden Terhadap value based pricing \\ Berdasarkan tanggapan responden mengenai} value based pricing, maka diperoleh rekapitulasi yang terdiri dari value is low price:discounting, penetration pricing $(X 1)$, value is quality: value pricing, market segmen pricing(X2). Pada Tabel 4 terdapat gambaran mengenai rekapitulasi tanggapan responden terhadap value based pricing.
TABEL 4

REKAPITULASI TANGGAPAN RESPONDEN TERHADAP VALUE BASED PRICING

\begin{tabular}{|c|l|c|c|c|}
\hline No. & $\begin{array}{c}\text { Sub } \\
\text { Variabel }\end{array}$ & $\begin{array}{c}\text { Total } \\
\text { Skor }\end{array}$ & $\begin{array}{c}\text { Skor } \\
\text { Rata- } \\
\text { Rata }\end{array}$ & $\%$ \\
\hline 1 & $\begin{array}{l}\text { Value is } \\
\text { low price }\end{array}$ & 1228 & 122.8 & 51.22 \\
\hline 2 & $\begin{array}{l}\text { Value is } \\
\text { quality }\end{array}$ & 1169 & 116.9 & 48.76 \\
\hline \multicolumn{2}{|c|}{ Total } & 2397 & 239,7 & 100 \\
\hline
\end{tabular}

Sumber: Hasil Pengolahan Data, 2010

Berdasarkan Tabel 4 dapat terlihat bahwa sub variabel dari value is low price yang terdiri dari discounting, penetration pricing yang mendapatkan penilaian paling besar yaitu pada discounting yaitu sebesar 866, dan item pertanyaan paling rendah adalah kesesuaian diskon yang ditawarkan dengan nilai sebesar 49,09, dan item item pertanyaan paling tinggi adalah kesesuaian diskon yang ditawarkan dengan nilai sebesar 50,11, itu artinya kesesuaian diskon yang ditawarkan oleh Taman Rekreasi memberikan keseuaian karena diskon yang ditawarkan Rp15.000-Rp10.000. Discounting yaitu menawarkan diskon atau potongan harga untuk mengkomunikasikan kepada para pembeli yang sensitif terhadap harga bahwa mereka mendapatkan nilai yang diharapkan.

Penetration pricing adalah menetapkan harga murah untuk suatu jasa baru dengan tujuan mendorong pencobaan produk dan pemakaian lebih luas. Dalam indikator penetration pricing terdapat jumlah nilai sebesar sebanyak $362 \%$. Penetration pricing yangditawarkan berupa harga murah dapat melakukan aktifitas dengan fasilitas suatu produk atau jasa seperti Little Venice. Taman Rekreasi Kota Bunga Cipanas juga menyediakan arena permainan untuk anakanak, permainan tersebut diberi nama Arena Fantasi. Permainan di Arena Fantasi ini antara lain terdapat bumper car, venture river, mandi bola, dan masih banyak lagi. Selain itu ditunjang dengan udara yang sejuk, atau alam yang indah karena alam merupakan salah satu atraksi wisata yang paling digemari wisatawan. Keindahan alam merupakan keindahan alami yang diberikan Sang Pencipta yang tidak dapat ditandingi oleh benda buatan manusia. Sumber daya alam dan lingkungan merupakan dasar dari industri pariwisata, dan salah satu alasan wisatawan melakukan perjalanan adalah untuk mendapatkan pengalaman keindahan alam, bunga, dan wahana. Sehingga total keseluruhan dari value is low price sebesar 1228 atau sebesar $51,22 \%$.

Sedangkan value is quality terdiri dari value pricing, market segmen pricing merupakan 
skor terendah. Dapat dilihat dari data rekapitulasi bahwa market segmen pricing memiliki skor sebesar 737, dan terendah adalah value pricing 431,Sehingga total keseluruhan dari value is quality sebesar 1169 atau sebesar 48,76, sehingga total paling besar dimiliki oleh value is low price sebesar 1228 atau sebesar $51,22 \%$.

Berdasarkan data mengenai value is low price paling tinggi maka diperkuat oleh teori Zeithaml and Bitner tahun 2009 bahwa harga murah berdasarkan nilai yang didapat. Sehingga dalam teori ini strategy dapat digunakan.

Secara keseluruhan variabel value based pricing dapat diketahui kedudukannya berdasarkan skor yang didapat di mana nilainilai tersebut dibandingkan dengan kriteria skor standar, yang didapat melalui perhitungan skor ideal (criterium) dan skor terkecil, sehingga melalui skor standar tersebut dapat diketahui daerah kontinium yang menunjukkan wilayah ideal dari variabel value based pricing, hal tersebut dapat dicari dengan rumus Sugiyono (2008:135) sebagai berikut:

Mencari skor ideal value based pricing:

Skor ideal $\Rightarrow$ Skor Tertinggi x Jumlah

Butir Item x Jumlah Responden

Skor ideal $\Rightarrow 5 \times 6 \times 100=3000$

Mencari skor terendah value based pricing: $\Rightarrow$

Skor ideal Skor Terendah x Jumlah

Butir Item x Jumlah Responden

Skor ideal $\Rightarrow 1 \times 6 \times 100=600$

Mencari panjang interval kelas value based pricing:

panjang interval kelas skor ideal : banyaknya kelas interval panjang interval kelas $\Rightarrow 300: 5=60$

Hasil dari rumus menurut (2008:135) ini digunakan dalam pembahasan hasil penelitian untuk mengetahui tangggapan terhadap value based pricing melalui gambar Garis Kontinum. Berdasarkan jumlah skor hasil pengumpulan data value based pricing adalah 2397 dengan demikian maka value based pricing menurut persepsi 100 responden adalah

(2397 : 3000) x 100\% = 79,9\%

Hasil ini secara kontinium dapat dibuat kategori sebagai berikut:

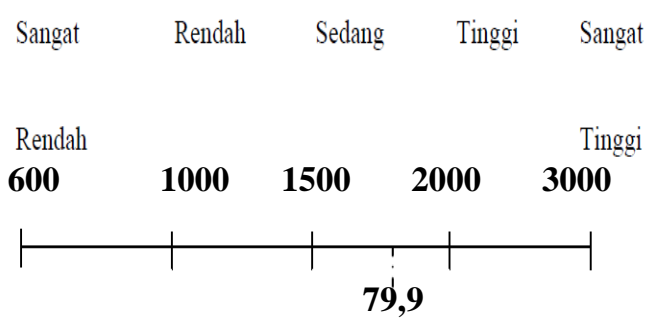

Nilai 2397 sesuai dengan data penelitian yaitu termasuk dalam kategori sedang dan tinggi tetapi lebih mendekati tinggi, Taman Rekreasi Kota Bunga menurut penilaian wisnus dalam kategori tinggi atau baik dengan persentase $79,9 \%$ dalam pelaksanaan program value based pricing di Taman Rekreasi Kota Bunga telah baik dilaksanakan oleh pihak Taman Rekreasi Kota Bunga.

\subsection{Tanggapan Responden Terhadap Keputusan Berkunjung}

TABEL 5

REKAPITULASI TANGGAPAN RESPONDEN TERHADAP KEPUTUSAN BERKUNJUNG DI TAMAN REKREASI KOTA BUNGA

\begin{tabular}{|c|c|c|c|c|}
\hline No. & Indikator & Total Skor & Skor Rata-Rata & \% \\
\hline 1 & Pemilihan Produk/Jasa & 1215 & 243 & 30,34 \\
\hline 2 & Pemilihan Brand (Merek) & 805 & 161 & 20,10 \\
\hline 3 & Waktu Kunjungan & 725 & 181,25 & 18,10 \\
\hline 4 & $\begin{array}{c}\text { Pemilihan penyalur } \\
\text { wisatawan }\end{array}$ & 871 & 77.2 & 21,75 \\
\hline 5 & Jumlah Kunjungan & 388 & 810.05 & 9,69 \\
\hline \multicolumn{2}{|c|}{ Total } & 4004 & & 100 \\
\hline
\end{tabular}

Sumber: Hasil Pengolahan Data, 2010

Tabel 5 menunjukan bahwa tanggapan responden dari kelima keputusan berkunjung yaitu pemilihan produk/jasa, pemilihan brand (merek), waktu kunjungan, pemilihan penyalur wisatawan, dan jumlah kunjungan yang tertinggi adalah pemilihan pemilihanproduk dan jasa yaitu sebesar
30,34\%. Hal ini dikarenakan pemilihan produk dan jasa memberikan kontribusi kepada wisatawan dengan fasilitas yang dirasakan. Sedangkan tanggapan responden yang terendah adalah jumlah kunjungan wisatawan yaitu sebesar 9,69\%. Hal ini 
disebakan wisatawan lebih berkunjung diwaktu weekend.

Berdasarkan data terbesar mengenai pemilihan produk/jasa diperkuat oleh teori Kotler and Armstrong tahun 2009 bahwa perusahaan harus memusatkan perhatian kepada ornag-orang untuk mengunjungi kawasan wisata yang mereka kelola, sehingga wisatawan dapat mengambil keputusan untuk mengunjungi atrkasi wisata tersebut.

Berdasarkan Tabel 4.26 rekapitulasi keputusan berkunjung dapat terlihat bahwa indikator dari keputusan berkunjung yang mendapatkan penilaian paling besar yaitu pada pemilihan produk/jasa yaitu sebesar $30,34 \%$, kemudian mereksebanyak 20,10\%, dan waktu kunjungansebanyak $18,10 \%$, dan pemilihan waktu penyalur sebanyak 21,75 , dan yang terakhir jumlah penyalur sebesar 9,69.Penilaian terbesar pada keputusan berkunjung yaitu sebesar $30,34 \%$, hal ini disebabkan pemilihan produk/jasa sangat puas yang di tawarkan oleh pihak Taman Rekreasi Kota Bunga, sehingga pengenalan wisnus akan produk dan jasa yang ditawarkan sebuah destinasi bisa terbentuk dengan cepat. Seperti yang diungkapakan Kotler dan Keller (2009:202)

\section{Pemilihan produk/jasa}

Konsumen dapat mengambil keputusan untuk membeli sebuah produk atau menggunakan uangnya untuk tujuan yang lain. Dalam hal ini perusahaan harus memusatkan perhatiannya kepada orangorang yang berminat membeli sebuah produk serta alternatif yang mereka pertimbangkan.

Perusahaan harus memusatkan perhatiannya kepada orang-orang yang berminat untuk mengunjungi kawasan wisata yang mereka kelola, sehingga wisatawan dapat mengambil keputusan untuk mengunjungi daya tarik wisata tersebut. Skor terendah yang didapatkan adalah pada dimensi jumlah kunjungan, hal ini disebabkan oleh kurangnya wisnus berkunjung di saat weekday, pengunjung dapat melakukan wisata diwaktu weekend, namun, adapun rombongan yang datang pada waktu weekday dan weekend hanya dikunjungi pada hari sabtu.

Secara keseluruhan variabel keputusan berkunjung dapat diketahui kedudukannya berdasarkan skor yang didapat di mana nilainilai tersebut dibandingkan dengan kriteria skor standar, yang didapat melalui perhitungan skor ideal (criterium) dan skor terkecil, sehingga melalui skor standar tersebut dapat diketahui daerah kontinium yang menunjukkan wilayah ideal dari variabel keputusan berkunjung, hal tersebut dapat dicari dengan rumus Sugiyono (2008:135) sebagai berikut:

\section{Mencari skor ideal keputusan berkunjung:}

Skor ideal $\Rightarrow$ Skor Tertinggi x Jumlah

Butir Item x Jumlah Responden

Skor ideal $\Rightarrow 5 \times 11 \times 100=5500$

Mencari skor terendah keputusan berkunjung:

Skor ideal $\Rightarrow$ Skor Terendah x Jumlah

Butir Item x Jumlah Responden

Skor ideal $\Rightarrow 1 \times 11 \times 100=1100$

Mencari panjang interval kelas keputusan berkunjung:

panjang interval kelas $\Rightarrow$ skor ideal : banyaknya kelas interval

panjang interval kelas $\Rightarrow 5500: 5=1100$

Hasil dari rumus menurut (2008:135) ini digunakan dalam pembahasan hasil penelitian untuk mengetahui tangggapan terhadap keputusan berkunjung melalui gambar Garis Kontinum. Berdasarkan jumlah skor hasil pengumpulan data keputusan berkunjung adalah 4004 dengan demikian maka keputusan berkunjung menurut persepsi 100 responden adalah

(4004: 5500) x 100\% $=72,8 \%$

Hasil ini secara kontinium dapat dibuat kategori sebagai berikut:

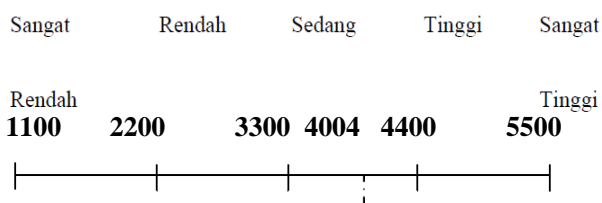

Nilai 4004 sesuai dengan data penelitian yaitu termasuk dalam kategori sedang dan tinggi tetapi lebih mendekati tinggi, jadi keputusan berkunjung di Taman Rekreasi Kota Bunga menurut penilaian wisnus dalam kategori tinggi atau baik dengan persentase $72,8 \%$.

\subsection{Hasil Analisis Data}

4.3.1. Pengujian Asumsi regresi

a) Uji Asumsi Normalitas

Syarat pertama untuk melakukan analisis regresi adalah normalitas, sebagaimana yang diungkapkan oleh Triton (2005:76) bahwa data sampel hendaknya memenuhi prasyarat distribusi normal. Data 
yang mengandung data ekstrim biasanya tidak memenuhi asumsi normalitas. Jika sebaran data mengikuti sebaran normal, maka populasi dari mana data diambil berdistribusi normal dan akan dianalisis menggunakan analisis parametrik.

Menurut Wahid Sulaiman (2004:88), untuk mendeteksi normalitas, digunakan Normal Probability Plot. Melalui plot ini, masing-masing nilai pengamatan dipasangkan dengan nilai harapan dari distribusi normal apabila sebaran data terletak di sekitar garis lurus yang melalui titik nol dan tidak mempunyai pola.

Gambar 4.8 nilai residu berdistribusi normal apabila sebaran datanya terletak di sekitar garis diagonal yaitu dari kiri bawah ke kanan atas. Dengan demikian berdasarkan Gambar 2 data memenuhi asumsi normalitas.
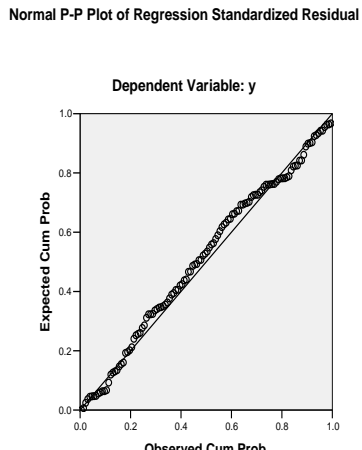

GAMBAR 2

NORMAL PROBABILITY PLOT

\section{b) Uji Asumsi Heteroskedastisitas}

Heteroskedastisitas adalah varian residual yang tidak konstan pada regresi sehingga akurasi hasil prediksi menjadi meragukan. Residu pada heteroskedastisitas semakin besar apabila pengamatan semakin besar. Menurut wahid Sulaiman (2004:106), suatu regresi dikatakan tidak terdeteksi heteroskedastis apabila penyebaran nilainilai residual terhadap harga-harga prediksi tidak membentuk suatu pola tertentu (meningkat atau menurun). Suatu regresi dikatakan tidak terdeteksi Heteroskedastisita apabila diagram pencar residualnya tidak membentuk pola tertentu, dan apabila datanya berpencar disekitar angka 35 (pada sumbu Y).

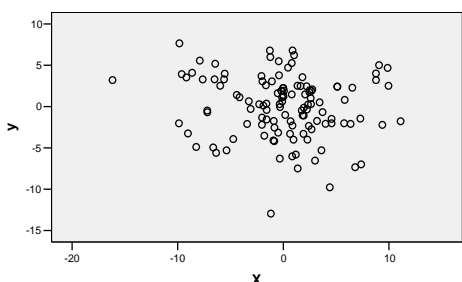

GAMBAR 3

UJI ASUMSI

HETEROSKEDASTISITAS

Berdasarkan Gambar 3 maka dapat dilihat bahwa sebaran data terdapat disekitar titik 35 dan tidak tampak adanya suatu pola tertentu pada sebaran data tersebut. Dengan demikian data yang akan dianalisis memenuhi asumsi heteroskedastisita.

\section{c) Pengujian Multikolinieritas}

Multikolinearitas artinya terdapat hubungan linear yang sempurna atau pasti diantara beberapa atau semua variabel yang menjelaskan dari model regresi, yaitu terdapatnya lebih dari satu hubungan linear pasti. Berdasarkan teori tersebut, maka dalam penelitian ini terdapat korelasi yang rendah antara variabel bebas dapat dijelaskan. Untuk mengetahui terjadinya multikolinearitas dalam penelitian ini digunakan matriks korelasi yang dihitung dengan bantuan paket program SPSS pada tabel 6 berikut:

TABEL 6

MATRIK KORELASI ANTAR VARIABEL BEBAS

\section{Correlations}

\begin{tabular}{|ll|c|c|l|}
\hline & & $\mathrm{y}$ & $\mathrm{x} 1$ & $\mathrm{x} 2$ \\
\hline Pearson Correlation & $\mathrm{y}$ & 1.000 & .419 & .376 \\
& $\mathrm{x} 1$ & .419 & 1.000 & .254 \\
& $\mathrm{x} 2$ & .376 & .254 & 1.000 \\
\hline
\end{tabular}

Berdasarkan Tabel 6 di atas menunjukkan bahwa korelasi antar variabel bebas tidak terdapat nilai yang melebihi 0.80 (semua kurang dari 0.80), dengan demikian tidak terjadi multikolinearitas, dengan 
mengacu pada Gujaratai (2003:362) mengemukakan bahwa apabila korelasi antar variabel bebas tidak terdapat nilai lebih dari 0.80 maka tidak terjadi multikolinearitas.

\subsubsection{Koefisien Korelasi dan Koefisien Determinasi}

Untuk mengetahui seberapa kuat hubungan dan seberapa besar pengaruh value based pricing yang terdiri value is low price:discounting, penetration pricing (X1), value is quality: value pricing, market segmen pricing $(\mathrm{X} 2)$, dapat dilihat melalui nilai koefisien korelasi dan determinasi.

TABEL 7

OUTPUT PENGARUH VALUE BASED PRICING TERHADAP KEPUTUSAN BERKUNJUNG TAMAN REKREASI KOTA BUNGA

\begin{tabular}{|c|c|c|c|c|c|c|c|c|c|}
\hline \multicolumn{10}{|c|}{ Model Summary } \\
\hline & & & & & \multicolumn{5}{|c|}{ Change Statistics } \\
\hline Model & $\mathrm{R}$ & R Square & $\begin{array}{l}\text { Adjusted } \\
\text { R Square }\end{array}$ & $\begin{array}{l}\text { Std. Error o } \\
\text { the Estimat }\end{array}$ & $\begin{array}{l}\text { R Square } \\
\text { Change }\end{array}$ & F Change & df1 & df2 & Sig. F Chang \\
\hline 1 & $.658^{2}$ & .433 & .418 & 3.73168 & .433 & 29.543 & 3 & 116 & .000 \\
\hline
\end{tabular}

Berdasarkan Tabel 7 diperoleh nilai koefisien korelasi value based pricing dengan keputusan berkunjung sebesar 0,658. Bila korelasi tersebut diinterpretasikan pada tabel korelasi maka hubungan antara value based pricing terhadap keputusan berkunjung memiliki hubungan yang kuat sesuai dengan klasifikasi koefisien korelasi menurut Sugiyono (2008:250).

Berdasarkan hasil perhitungan, nilai koefisien determinasi adalah 0,433 atau
43,3\%. Hal ini menunjukkan bahwa secara bersama-sama variabel value based pricing memberikan kontribusi $43,3 \%$ terhadap keputusan berkunjung.

\subsubsection{Pengujian Hipotesis dan Uji Signifikansi Secara Simultan (Uji F) Untuk menguji signifikasi dapat digunakan uji $\mathrm{F}$, untuk lebih jelasnya mengenai output ANOVA dapat dilihat pada Tabel 4.20}

\section{TABEL 8 \\ OUTPUT ANOVA}

\begin{tabular}{|c|c|c|c|c|c|c|}
\hline \multicolumn{7}{|c|}{ ANOVA $^{b}$} \\
\hline \multicolumn{2}{|c|}{ Model } & $\begin{array}{l}\text { Sum of } \\
\text { Squares }\end{array}$ & df & Mean Square & $\mathrm{F}$ & Sig. \\
\hline \multirow[t]{3}{*}{1} & Regression & 1234.194 & 3 & 411.398 & 29.543 & $.000^{a}$ \\
\hline & Residual & 1615.352 & 116 & 13.925 & & \\
\hline & Total & 2849.546 & 119 & & & \\
\hline
\end{tabular}

Berdasarkan Tabel 8 di atas, diperoleh nilai $F_{\text {hitung }}=29,543$ sedangkan $F_{\text {tabel }}$ dengan derajat kebebasan pada $\alpha$ (0.05) adalah sebesar 2,72 Dengan demikian $F_{\text {hitung }}$ $(29,543)>F_{\text {tabel }}(2,72)$ dengan nilai signifikansinya 0,000 . Nilai signifikansi lebih kecil dari taraf signifikansi 5\%, sehingga jelas H0 ditolak dan Ha diterima. Dengan nilai signifikansi 0,000 nilai signifikansi lebih kecil dari taraf signifikansi 5\% maka regresi dapat digunakan untuk memprediksi keputsan berkunjungg di Taman Rekreasi Kota Bunga atau variabel value based pricing berpengaruh terhadap keputusan berkunjung pada taraf kepercayaan $95 \%$. berikut

Hipotesis dalam penelitian ini sebagai

$\mathrm{Ha} \neq 0$, Terdapat pengaruh signifikan value based pricing terhadap keputusan berkunjung di Taman Rekreasi Kota Bunga.

Hal ini dapat dibuktikan dengan keputusan berkunjung yang diberikan wisatawan terhadap suatu destina diciptakan dari persepsi wisatawan terhadap destinasi melalui pemilihan produk/jasa atau penjelasan lain hal yang akan memudahkan 
wisatawan memiliki asosiasi dengan destinasi tersebut. Seperti yang dikatakan Lovelock (2011:160) mengungkapkan bahwa value based pricing adalah penetapan harga dilihat dari nilai produk yang dirasakan oleh pelanggan baik manfaat ekonomis, fungsional, maupun psikologis. Dengan pendekatan value based pricing, banyak perusahaan yang berhasil membangun skema harga yang lebih baik dan lebih memahami apa-apa saja yang membuat konsumen bersedia merogoh koceknya. Dibalik berbagai tantangan yang harus dihadapi perusahaan, ada beberapa cara untuk mengatasi hambatan-hambatan untuk menentukan kebijakan harga. Perusahaan harus berfokus pada tiga hal sebagai berikut:

Fokus kepada nilai pelanggan dalam hal ini, perusahaan jangan terlalu menekankan pada fitur-fitur produk yang mereka tawarakan atau hanya pada harga produk tersebut, tapi yang lebih penting perusahaan harus lebih focus pada berbagai manfaat, baik manfaat fungsional atau emosional yang dapat diterima pelanggan dari produk tersebut.

Memberikan diferensiasi pada produk dan layananproduk atau layanan yang diberikan perusahaan haruslah memiliki nilai yang lebih tinggi dari pesaing. Jika tidak, maka perusahaan akan terjebak dalam situasi dimana perusahaan akan dipaksa bermain perang harga. Hal ini akan secara efektif menghancurkan kemampuan perusahaan untuk menetapkan harga premium. Artinya jika sebuah perusahaan tidak dapat membuat diferensiasi maka perusahaan tersebut akan kesulitan dalam menetapkan harga berdasarkan nilai atau manfaat yang dapat diberikannya.

Mengerti dan mengkomunikasikan semua sumber nilai yang potensial untuk dapat menjalankan value based pricing dengan baik, maka perusahaan sebaiknya memahami nilai atau manfaat yang diterima pelanggan. Artinya perusahaan harus dapat memahami apa yang menjadi keinginan dan kebutuhan pelanggan. Jika perusahaan sudah memahami hal ini maka hal selanjutnya adalah mengkomunikasikan manfaat dari produk kepada pelanggan bahwa produk yang pelanggan konsumsi mempunyai manfaat bagi dirinya. Lebih hebat lagi apabila manfaat dari produk tersebut melebihi harapan dari si pelanggan, maka besar kemungkinan akan menciptakan pelanggan yang loyal. Value based Pricing, penetapan harga dilihat dari nilai produk yang dirasakan oleh pelanggan baik manfaat ekonomis, fungsional, maupun psikologis.

\subsubsection{Pengujian Hipotesis dan Signifikansi Secara Pasial (Uji t)}

TABEL 9

OUTPUT KOEFISIEN REGRESI

Coefficients

\begin{tabular}{|c|c|c|c|c|c|c|}
\hline \multirow{2}{*}{\multicolumn{2}{|c|}{ Model }} & \multicolumn{2}{|c|}{$\begin{array}{l}\text { Unstandardized } \\
\text { Coefficients }\end{array}$} & \multirow{2}{*}{$\begin{array}{c}\text { Standardized } \\
\text { Coefficients }\end{array}$} & \multirow[b]{2}{*}{$t$} & \multirow[b]{2}{*}{ Sig. } \\
\hline & & $\mathrm{B}$ & Std. Error & & & \\
\hline 1 & (Constant) & 4.166 & 3.905 & & 1.067 & .288 \\
\hline & $\mathrm{x} 1$ & .469 & .071 & .369 & 6.614 & .000 \\
\hline & $x 2$ & .246 & .097 & .196 & 2.531 & .013 \\
\hline
\end{tabular}

a. Dependent Variable: y

*) $\mathrm{t}_{\text {table }}=\mathrm{df}: 120-3-1=1,98$

Untuk menguji dimensi dari variable value based pricing maka dapat digunakan distribusi t-hitung, dapat dijelaskan sebagai berikut:

1. Hasil uji t parsial dapat diketahui bahwa nilai t hitung untuk dimensi value is low pricie sebesar 6,614>1,98, ini berarti bahwa terdapat pengaruh yang signifikan antara dimensivalue is low price dengan keputusan berkunjung.

2. Hasil uji t parsial dapat diketahui bahwa nilai $\mathrm{T}$ hitung untuk dimensi value is qualityv(X2) sebesar 2,531>1,98, ini berarti bahwa terdapat pengaruh yang 
signifikan antara dimensi value is quality dengan keputusan berkunjung.

\subsubsection{Model Persamaan Regresi \\ Pengaruh value based pricing \\ Terhadap Keputusan berkunjung di Taman Rekreasi Kota Bunga \\ Hasil analisa data dengan bantuan pengolahan komputer berdasarkan perhitungan SPSS 18 for windows diperoleh persamaan regresi sederhana sebagai berikut}

$Y=a+b_{1} X_{1}+b_{2} X_{2}$

Berdasarkan hasil pengolahan data maka persamaan regresi untuk value based pricing adalah:

$$
\begin{aligned}
& \mathrm{Y}=\mathbf{4 , 1 6 6}+\mathbf{0 . 4 6 9}(\mathrm{X} 1)+\mathbf{0 . 2 4 6}(\mathrm{X} 2) \\
& \text { Dimana, } \\
& \mathrm{Y}=\text { keputusan berkunjung } \\
& \mathrm{X} 1=\text { value is low price } \\
& \mathrm{X} 2=\text { value is quality }
\end{aligned}
$$

Berdasarkan persamaan di atas, maka nilai koefisien regresi dapat dijelaskan sebagai berikut:

1. Value is low price $\left(\mathrm{X}_{1}\right)=0,469$ maka perubahan value is low price sebesar satu satuan akan menimbulkan kontribusi sebesar $4,166+0,469(1)=4.635$ terhadap keputusan berkunjung.

2. value is quality $\left(\mathrm{X}_{2}\right)=0,246$ maka perubahan value is quality sebesar satu satuan akan menimbulkan kontribusi sebesar 4,166+0,246(1) $=4.412$ terhadap keputusan berkunjung.

\subsubsection{Hasil Uji Asumsi Sub Variabel}

Pengujian hipotesis ditujukan untuk menguji besarnya pengaruh value based pricing $(\mathrm{X})$ yang terdiri dari value is low price $(\mathrm{X} 1)$, value is quality (X2) terhadap keputusan berkunjung (Y). Tabel 10 berikut merupakan hasil korelasi antara value based pricing dengan keputusan berkunjung:
TABEL 10

MATRIKS KORELASI ANTAR SUB

VARIABEL VALUE BASED PRICING DENGAN KEPUTUSAN BERKUNJUNG

\begin{tabular}{|l|l|}
\hline \multicolumn{2}{|c|}{ Y } \\
\hline Y & 1.000 \\
\hline X1 & 0,419 \\
\hline X2 & 0,376 \\
\hline
\end{tabular}

Sumber : Pengolahan Data, 2011

Berdasarkan hasil korelasi matriks antara sub variabel value based pricing dengan keputusan berkunjung, diperoleh hasil korelasi yaitu, value is low price $(0,419)$, value is quality $(0,376)$ value is low price memperoleh koefisien korelasi terbesar, hal ini menujukan bahwa antara value is low price dengan keputusan berkunjung memiliki hubungan yang kuat dibandingkan dengan value is quality.

Rumusan hipotesis yang diajukan dalam penelitian ini adalah:

Ho:Pyx =0: tidak berpengaruh value based pricing terhadap keputusan berkunjung

H1:Pyx $\neq 0$ : terdapat pengaruh value based pricing terhadap keputusan berkunjung

Dari hasil perhitungan dengan menggunakan SPSS 18, sebagai berikut:

1. Koefisien korelasi antara value is low price (X1) dengan keputusan berkunjung $\mathrm{r}=0,419$, ini berarti terdapat hubungan yang cukup erat antara value is low price dengan keputusan berkunjung. Jika diinterpretasikan korelasi value is low price dengan keputusan berkunjung adalah cukup erat dan arahnya positif ini berarti apabila value is low price baik maka keputusan berkunjung akan meningkat.

2. Koefisien korelasi antara value is quality (X2) dengan keputusan berkunjung $r=$ 0,376 ini berarti terdapat hubungan yang rendah antara value is quality dengan keputusan berkunjung. Jika diinterpretasikan korelasi value is quality dengan keputusan berkunjung adalah rendah dan arahnya positif ini berarti apabila value is quality baik maka keputusan berkunjung akan meningkat. 


\subsection{Pembahasan Hasil Penelitian}

Hasil pengujian hipotesis menunjukan bahwa value based pricing memiliki pengaruh yang significant terhadap Kepuasan wisnus yaitu dengan nilai korelasi sebesar 0,658 yang artinya menunjukan tingkat korelasi yang kuat. Sementara besarnya pengaruh value based pricing terhadap keputusan berkunjung adalah 43,3\%.

Persamaan regresi yaitu:

$\mathrm{Y}=4,166+0.469(\mathrm{X} 1)+0.246(\mathrm{X} 2)$

Hasil pengujian hipotesis menunjukan bahwa setiap dimensi dari value based pricing menunjukkan hasil yang positif yaitu:

1. Jika value is low price dinaikan sebesar satu-satuan maka keputusan berkunjung akan meningkat sebesar 0,469 , artinya value is low price memberikan pengaruh yang sedang terhadap keputusan berkunjung sebesar $46,9 \%$.

2. Jika value is quality dinaikan sebesar satu-satuan maka keputusan berkunjung akan meningkat sebesar 0,246 , artinya value is quality memberikan pengaruh yang rendah terhadap keputusan berkunjung sebesar $24,6 \%$.

Berdasarkan hasil penelitian ini dapat disimpulkan bahwa value based pricing memiliki pengaruh yang signifikan yaitu dengan tingkat signifikan 0,000 nilai signifikansi lebih kecil dari taraf signifikansi 5\% dipengaruhi melalui value based pricing dengan taraf kepercayaan sebesar $95 \%$. Setiap indikator value based pricing yang diteliti menunjukan bahwa indikator value is low price memberikan pengaruh yang tinggi, value is quality memberikan pengaruh yang rendah.

Hasil analisis regresi di atas memberikan hasil adanya pengaruh antara value based pricing dengan keputusan berunjung yang memberikan penjelasan sebagai berikut:

Pengaruh keputusan berkunjung terhadap keputusan berkunjung pada uji $t$ menunjukkan bahwa:

1. Hasil uji t parsial dapat diketahui bahwa nilai $\mathrm{T}$ hitung untuk dimensi value is low price (X1) sebesar 6,614>1,98, ini berarti bahwa terdapat pengaruh yang signifikan antara dimensi value is low price dengan keputusan berkunjung.

2. Hasil uji t parsial dapat diketahui bahwa nilai $\mathrm{T}$ hitung untuk dimensi value is quality (X2) sebesar 2,531>1,98, ini berarti bahwa terdapat pengaruh yang signifikan antara dimensi value is quality terhadap keputusan berkunjung.

Hasil analisis pengaruh value based pricing berdasarkan uji f menunjukkan bahwa variabel bebas tersebut berpengaruh positif terhadap keputusan berkunjung. Hal ini ditunjukkan oleh Fhitung $>$ Ftabel dengan derajat bebas pembilang dua dan penyebut 116 menunjukkan bahwa nilai sig $(0,000)$ lebih kecil dari taraf nyata $5 \%$ atau $\mathrm{F}$ hitung $>$ Ftabel $(29,543$ >2,68). Sehingga terdapat pengaruh yang signifikan (bermakna) antara variabel value based pricing terhadap keputusan berkunjung.

Berdasarkan hasil perhitungan, nilai koefisien determinasi adalah 0,433 atau 43,3\%. Hal ini menunjukkan bahwa secara bersama-sama variabel value based pricing memberikan kontribusi 43,3\% terhadap keputusan berkunjung.

\section{KESIMPULAN}

Berdasarkan hasil penelitian secara deskriptif dan verifikatif dapat disimpulkan sebagai berikut:

1. Sebagian besarwisnus menyatakan bahwa pelaksanaan value based pricing yang terdiri dari value is low price, value is quality berada pada kategori tinggi, hal ini berarti bahwa pelaksanaan program value based pricing sudah baik. Sebagian besar wisnus memilih value is low price diikuti oleh value is quality. Indikator pada value is low price yang paling tinggi adalah pada discount yang ditawarkan Rp15000-Rp10.000, kemenarikan aktivitas wisata Taman Rekreasi Kota Bunga kemenarikan daya tarik wisata, kemudahan alat transportasi untuk mencapai wisata alam cianjur. Indikator pada value is quality yang paling tinggi adalah pada market segmen pricing, Ketersediaaan market segmen pricingyang terdiri harga yang berbeda untuk segmen dari anak-anak sampai dewasa dengan fasiltas yang ada seperti menyediakan arena permainan untuk anak-anak, permainan tersebut diberi nama Arena Fantasi. Permainan di Arena Fantasi ini antara lain terdapat bumper car, venture river, mandi bola, dan masih banyak lagi. Selain itu ditunjang dengan udara yang sejuk, serta little venice yang dibangun tahun 2001, security centre, fasilitas P3K, diikuti oleh Keorisinalitasan daya tarik wisata yang 
ditawarkan diikuti oleh, Ketersediaan support tourist facilities yang terdiri dari akomodasi, restauran, souvenir shop, Kelengkapan basic facilities yang terdiri dari toilet, tempat sampah, sarana ibadah, security centre, fasilitas $\mathrm{P} 3 \mathrm{~K}$, Kemenarikan daya tarik wisata,Ketersediaan alat transportasi, kemudian Kelengkapan support tourist facilities (Akomodasi, restoran, souvenir shop dll.), Hampir seluruhnya wisnus menyatakan bahwa keputusan berkunjung berada pada kategori tinggi, hal ini berarti bahwa keputusan berkunjung sudah baik, hal ini dapat dilihat dari indikator paling dominan hingga yang terendah.

2. Value Based Pricing mempunyai pengaruh yang positif terhadap Keputusan Berkunjung di Taman Rekreasi Kota Bunga

\section{DAFTAR PUSTAKA}

Buchari, Alma. (2008). Manajemen Pemasaran dan Pemasaran Jasa. Alfabeta,Bandung.

Fandy Tjiptono Gregorius Chandra dan Dedi Adriana (2008). Pemasaran Strategik. Yogyakarta. (2008). Strategi Pemasaran Edisi III. Yogyakarta: Andi

Ali Hasan. (2009). Edisi Baru Marketing. Yogyakarta: Media Pressindo

Asep Hermawan., (2006), Penelitian Bisnis Paradigma Kuantitatif, Jakarta: Gramedia Widiasarana Indonesia.

Bitner and Zeithaml (2009). Strategic Management

Lovelock, Chirstoper, Wirtz J., and Chew P. (2009). Essentials of Services Marketing. Singapore: Prentice Hall

Freddy Rangkuti. (2008). The Power of Brands. PT Gramedia Pustaka Utama: Jakarta.

Griffin, Jill, (2005), “Customer Loyalty” : Menumbuhkan Mempertahankan

Kesetiaan Pelanggan : Kata Pengantar: Robert T. Heres, alih bahasa,

Dwi Kartini Yahya, Jakarta: Erlangga

Husein Umar, 2007. Metode Riset Bisnis, PT Gramedia Pustaka Utama, Jakarta.

Husein Umar. (2009). Metode Penelitian Untuk Skripsi dan Tesis Bisnis Edisi Kedua. Jakarta: Rajawali Pers

Jim Blythe, (2007), Consumer Behaviour
Harun Al Rasyid. (1994). Teknik Penarikan Sampel dan Penyusunan Skala. Bandung: Program Studi Ilmu Sosial Bidang Kajian Utama Sosiologi Antropologi Program Pasca Sarjana UNPAD

Kotller, Philip dan Keller, Kevin Lane (2009). Marketing Management $13^{\text {th }}$ edition. New Jersey: Prentice Hall (2008). Principles of Marketing. New Jersey: Prentice Hall.

(2006). Marketing for Hospitality and Tourism. Prentice Hall.

Kurtz David L. , H. F. MacKenzie, Kim Snow - 2009, Marketing

Levy, Michael dan Barton A. Weitz (2007). Retailing Management 6th edition,

McGraw Hill International

McCarthy. (2008). Pemasaran Dasar 1. Penerbit Salemba Empat, Jakarta.

Pusat Pengolahan Data dan Sistem Jaringan (P2DSJ) 2009

Schiffman, Leon.G. dan Kanuk, Leslie. (2007). Consumer Behavior. Prentice

Hall InternasionalInc.

Suharsimi Arikunto, (2009), ProsedurPenelitian Suatu Pendekatan Praktis, Yogyakarta: Bina Aksara.

Fandy Tjiptono. (2006). Pemasaran Jasa. Andi. Yogyakarta

Sugyono, (2011) Metode Penelitian Bisnis, Bandung: CV Alfabeta.

Ulber Silalahi, (2009), Metode Penelitian Sosial, PT Refika Aditama, Bandung.

Kotler, Philip and Amstrong, Gary. (2008). Principles of Marketing $12^{\text {th }}$ edition. New Jersey: Prentice Hall

(2009). Principles of Marketing $13^{\text {th }}$ edition. New Jersey: Prentice Hall Manajemen Pemasaran Edisi 13 Jilid 1. Jakarta: Erlangga

Lamb, Charles W., Hair Jospeh F., McDaniel C. (2001). Pemasaran Edisi Kedua. Jakarta: Salemba Empat

. (2009). The Essential of Marketing. USA: Cengage Learning

Journal

Journal Pricing Strategy berdasarkan Value Based Pricing, 2007, Natalie 
Hedrick, Harmen Oppewal, Michael Beverland

Journal Analyzing the influence ofPricing Strategy berdasarkan Value Based Pricing to customer satisfaction

dining experience in the Golden River restaurant, 2009, Chandra, Grace

Journal Pricing andRevenue Management 2009, Sheryl E.Kimes
Jurnal Pricing In Service 2009, Stowe Shoemaker and Anna S.Mattila "service have characteristics that make pricing in a different service with the goods".

Situs Website

www.google.com

www.cianjurkab.go.id

www.kabarindonesia.com

www.kebunrayabogor.com

www.tamanrekreasi.com 
